\title{
EVALUASI ASPEK FUNGSI, ESETIKA DAN AGRONOMIS TANAMAN TEPI JALAN DI JALAN IJEN KOTA MALANG
}

\author{
Murdaningsih \\ Program Studi Agroekoteknologi, Fakultas Pertanian, Universitas Flores \\ ningsih_murda@yahoo.co.id
}

\begin{abstract}
Evaluating the Aesthetic Agronomical and Functional aspects of Side Street Plants At Ijen Street, Malang.

The research's general objective was to study and evaluate; the function, aesthetic and agronomical aspects of side street plants at Ijen Street, Malang. Plant evaluation was needed to optimize plant effectiveness on the side of the streets, in realizing the city's road concept that gives fluentness, safety, and improving environmental and street visual quality. This is important especially for the side street plants to fulfill architectural, functional, and aesthetical values for city environment.

There was lack of functional effectiveness at the traffic island as a site, caused by none continuation of tree planting. At one segment of the street the trees were physical and visual barriers causing the inconvenience of concealing clear view. All segment of Ijen Street don't have the function of a collision buffer. There was a windbreak function created by plant settlement with a corridor form. Plant function as sun control was accommodated in all of street segments. Generally, the plant cover function by the plants has not been completed. The erosion control was accommodated by plant settlement at the traffic island in the street of Ijen. Plants function as noise control and identity was fulfilled with the existence of Rhoistonia reggia trees along the street. The function of pollution control was lacking from the existing plants in Ijen Street. Overall the plants of Ijen Street have a lot of functions that helps the site to improve environmental quality.

Assessment of the esthetic aspect obtained from election of plant types and a planting plan revealed that improvement to support the development function was required. according of plant as agronomy value the existing plants can support plant function and add esthetical value, .
\end{abstract}

Keywords: evaluation, function, esthetic, agronomic, side street planting

\section{PENDAHULUAN}

Jalan Ijen merupakan salah satu jalan utarna di Kota Malang. Ruasan jalan Ijen yang cukup lebar masih memungkinkan terjadi perubahan pada penataan jalur hijau jalan. Aktivitas yang terdapat disepanjang jalan meliputi aktivitas pendidikan, perdagangan, dan pelayanan. Pada hari- hari libur, trotoar jalan sering pula digunakan sebagai sarana untuk aktivitas olahraga. Penataan jalur hijau sepanjang jalan Ijen didasarkan pada tujuan yang akan dicapai dan disesuaikan dengan karakter lingkungan setempat sehingga terbentuk lanskap jalan raya dengan ciri khas tertentu.

Jalan harus memenuhi aspek 
efisiensi, keamanan, kenyamanan serta penampilan yang menyenangkan untuk memperlancar sirkulasi dan mengantisipasi efek-efek yang ditimbulkannya seperti polusi, kebisingan, panas, dan ketidaknyamanan. Salah satu faktor yang dapat mewujudkan hal tersebut adalah ketepatan dalam penataan lanskap jalan raya, khususnya dalam penataan jalur hijau jalan. Selain permasalahan tersebut dampak lain dari statusnya sebagai ruang terbuka kota (Public space) yang pengelolaannya dilakukan oleh Pemerintah Kota dengan dana dan waktu yang umumnya terbatas, rnenuntut pemilihan tanarnan dan pola penataan yang tepat, fungsional dan estetis.

Tanaman berperan sebagai unsur pelembut dan dapat mengharmoniskan ruang-ruang dalam lanskap jalan. Fungsi tanaman dalam desain penanaman untuk mengurangi cahaya yang menyilaukan baik darimatahari maupun dari cahaya kendaraan dengan menempatkan tanaman pada ketinggian dan kepadatan yang tepat, untuk privasi, sebagai pengarah, sebagai pembentuk ruang, sebagai pembatas fisik yang mengendalikan pergerakan manusia, hewan dan kendaraan, mengkontrol iklim mikro (suhu, radiasi matahari, angin, presipitasi, kelembaban, mengurangi kecepatan angin dan memberi naungan), prepitasi, kontrol kebisingan, penyaringan dan pengkayaan udara, pengendalian erosi dan sebagai habitat satwa liar.

Menurut Chaniago (1980), pemilihan jenis pohon untuk jalan raya harus memperhatikan karakteristiknya, seperti (a). Naungan, yang sangat berhubungan dengan penetrasi radiasi matahari sehingga suhu udara disekitar tanaman menjadi menurun, (b). Akar harus cukup kuat untuk menahan vibrasi yang disebabkan oleh kendaraan yang lewat, dan jenis yang dipakai sebaiknya tidak mempunyai akar yang dapat menembus permukaan aspal atau beton sehingga kerusakan utilitas dapat dihindari, (c). Batang dan cabang cukup elastis dan kuat untuk menjaga rusaknya pohon bila angin bertiup kencang. Pendapat ini didukung oleh Nurisjah (1991) yang memberikan persyaratan agar tinggi dan besar pohon tidak mengganggu sarana dan prasarana kota yang ada disepanjang jalan serta prefereni satu jenis tanaman pada satu bagian jalur tertentu untuk memberikan kesan rapi dan orientasi.

Evaluasi tanaman pada tepi jalan diperlukan untuk mengoptimalkan efektivitas tanaman pada jalur jalan dalam mewujudkan konsep jalan dalam kota yang memberi kelancaran, keselamatan dan peningkatan kualitas lingkungan serta visual jalan. Demikian pentingnya peranan tanaman dalam lanskap jalan, khususnya untuk pemenuhan fungsi arsitektural, fungsional, lingkungan dan estetika.

\section{METODE}

Evaluasi tanaman tepi jalan dilakukan di jalan Ijen kota Malang Jawa Timur. Lokasi yang diamati sepanjang ruas jalan Ijen. Penelitian dilakukan selama 8 bulan.

Penelitian yang dilakukan bersifat deskriptif dengan metode survey, hal tersebut ditujukan untuk membuat deskripsi secara sistematis, faktual dan akurat mengenai aspek - aspek fungsi, estetika dan agronomi tanaman tepi jalan. Proses evaluasi pada penelitian ini dijabarkan dalam tiga tahap yaitu pengambilan data, analisis data dan perumusan rekomendasi seperti yang dirumuskan pada gambar 1 berikut : 


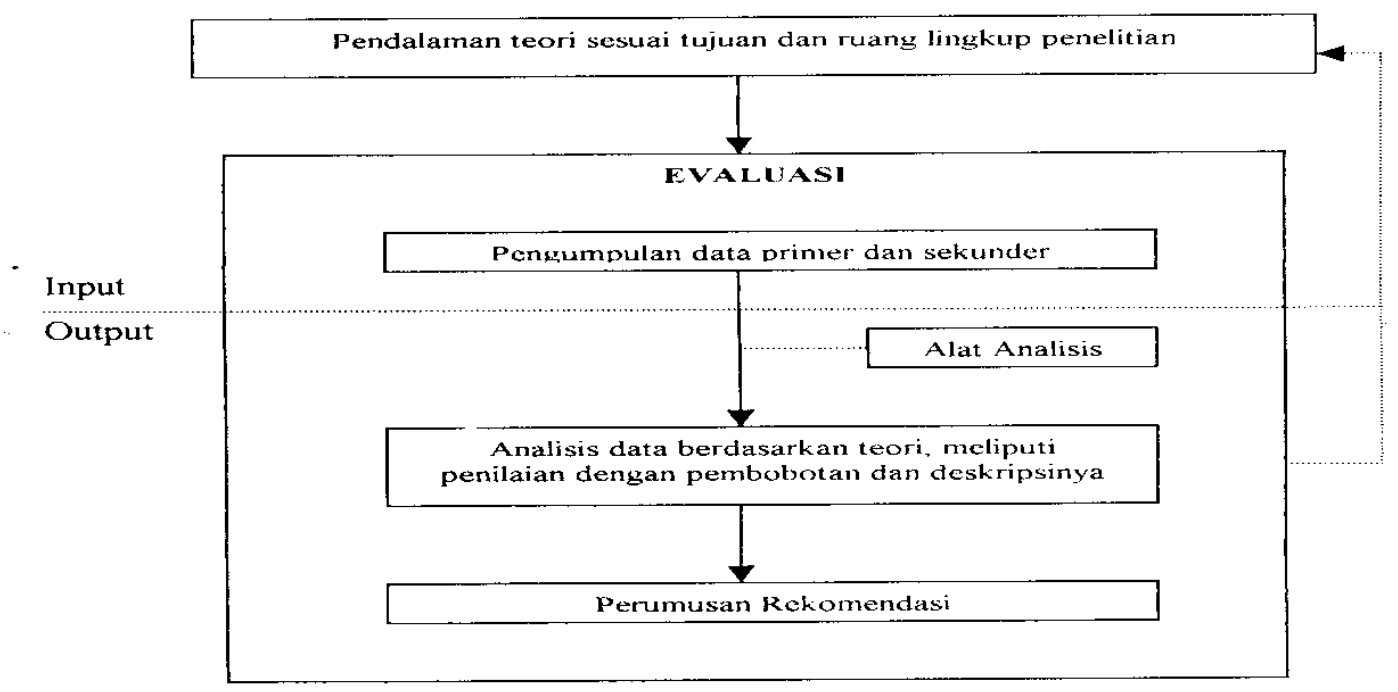

Gambar 1. Proses Evaluasi

Pengamatan dilakukan dengan menginventarisasi jenis-jenis tanaman yang di digunakan pada jalur hijau dan Fungsi-fungsi tanaman yang diamati meliputi: 1.)Pengarah 2). Peneduh 3). Pembatas 4). Penahan erosi. 5)Penahan benturan 6) . Perendam kebisingan 7). Penahan angin. 8) Pereduksi polusi. 9).Kontrol kesilauan.10). Pemberi identitas

Aspek estetika yang diamati meliputi variasi jenis tanaman dan penerapan unsur disain (garis, bentuk, ukuran) serta prinsip disain (tema, repetisi, kontras, dan keseimbangan) dalam komposisi tata hijau tanaman tepi jalan juga konsistensi bentuk, warna dan tekstur tanaman serta kontinyuitas penanarnan. Diamati pula pembentukan bayangan dari tajuk tanaman yang dapat mewujudkan kesatuan dengan lingkungan sekitar.

Pengamatan aspek agronomis lebih ditekankan pada penanganan tanaman pasca tanam yang dilakukan pengelola seperti penyiraman, penyiangan, pendangiran, pemangkasan, pemupukan, pengendalian hama dan penyakit tanaman.

Tahap akhir evaluasi yang akan melahirkan rekomendasi untuk perbaikan aspek fungsi, estetika dan agronornis tanaman tepi jalan.

\section{HASIL DAN PEMBAHASAN}

\section{Penilaian Aspek Fungsi Tanaman Tepi Jalan}

Taman tepi jalan Ijen didominasi oleh tanaman palem raja, dimana tata letak tanaman palem raja dapat menjadi suatu identitas taman yang ada di kota Malang. Barisan batang tanaman palem raja seolah sebagai pagar atau tembok yang berdiri kokoh disepanjang jalan ijen.

Tabel 2. Data Jumlah tanaman palem raja:

\begin{tabular}{lccc}
\hline \multicolumn{1}{c}{ Letak tanaman } & Tanaman utama & Tanaman Peremajaan & Jumlah \\
\hline Sebelah Timur & 149 & 101 & 250 \\
Sebelah barat & 140 & 119 & 259 \\
\hline
\end{tabular}

1. 


\section{Pengarah}

Pendapat responden untuk fungsi pengarah di DAMIJA 38,46\% responden menyatakan sangat baik, dan $61,54 \%$ responden menyatakan baik.Hal ini pada lokasi studi diperlihatkan dengan adanya tegakan batang pohon palem raja yang mendominasi ruasan kiri dan kanan jalan yang memberikan kesan rapi. Menurut Nurisjah (1991) preferensi satu jenis tanaman pada satu bagian jalur tertentu dapat memberikan kesan rapi dan orientasi. Penataan tata hijau dengan fungsi pengarah telah menerapkan pola penanaman berjajar mengikuti bentuk aligment jalan dengan baik. Sehingga terbentuk koridor yang dapat mengarahkan dan membantu pengemudi melakukan pergerakan pada satu titik tertentu.

Fungsi pengarah pada median jalan, $46,15 \%$ responden menyatakan baik dan $30,77 \%$ menyatakan sangat baik serta $23,08 \%$ menyatakan buruk. Pada median jalan jenis tanaman yang digunakan sudah bervariasi, baik dan jenis maupun warnanya.

Tanaman pengarah pada daerah DAMIJA disarankan untuk ditanam secara massal atau berbaris, jarak tanam rapat dan tidak terputus. Penggunaan jenis-jenis pohon yangmemiliki bentuk tajuk kolumnar atau piramidal atau tanaman yang berdaun jarum seperti glodogan Tiang, palem putri, angsana, cemara kipas, cemara angin, mahoni, hujan mas, dan kembang merak sangat disarankan. Untuk jenis perdu disarankan penggunaan jenis akalipa hijau kuning, pangkas kuning, teh-tehan, soka dan terang bulan. Untuk pengarah jalan di daerah milik jalan pada tikungan adalah cemara angin, glodokan tiang, bambu (Departemen PU, 1996).

\section{Pembatas}

Pendapat responden untuk fungsi Pembatas di DAMIJA 69,23\% responden yang menyatakan baik dan $30,77 \%$ menyatakan sangat baik. Fungsi pembatas pada pulau lalu lintas, masing-masing sebanyak 46,15 $\%$ menyatakan sangat baik dan baik dan $7,69 \%$ responden menyatakan buruk

Fungsi tanaman sebagai pembatas lebih berfungsi sebagai penghalang fisik Carpenter at al (1975) menyatakan bahwa tanaman dapat pula difungsikan sebagai penghalang fisik yang bertujuan untuk menahan gerak manusia, hewan dan kendaraan dari luar jalan serta penyangga kecelakaan untuk meminimalisasi kerusakan yang dapat terjadi. Seperti pada lokasi studi, keberadaan tanaman di jalur hijau pada damija berfungsi memisahkan jalur pedestrian dengan badan jalan, sementara jalur hijau pada median berfungsi untuk memisahkan ruas kiri dan kanan jalan.

Tanaman pembatas sebaiknya merupakan tanaman tinggi, perdu atau semak dengan ketinggian $>1,5 \mathrm{~m}$, memiliki massa daun padat, percabangan lentur, ditanam berbaris atau membentuk massa dengan jarak tanam < 3 m (Departernen PU, 1996). Ditambahkan pula jenis tanaman yang cocok sebagai pembatas adalah bambu, cemara angin, glodogan tiang, kembang sepatu, pangkas kuning .

\section{Penahan Benturan}

Penahan benturan merupakan turunan dari fungsi tanaman sebagai peredam kecelakaan. Responden yang menyatakan baik 46,15\%, 30,77\% menyatakan sangat baik dan 23,08\% menyatakan buruk. Fungsi penahan benturan pada median jalan $61,54 \%$ 
responden yang menyatakan baik dan 38,46 \% menyatakan buruk.Sedangkan pada pulau lalu lintas $46,15 \%$ responden menyatakan baik, 38,46\% menyatakan buruk dan masing-masing $7,69 \%$ menyatakan sangat baik dan sangat buruk.

Pemilihan dan peletakan tanaman untuk fungsi penahan benturan sesuai dengan kriteria belum diterapkan dengan baik. Pada lokasi penelitian baik pada jalur hijau tepi maupun pada median, pemilihan penis pohon lebih dominan, dan tidak dikombinasikan dengan penggunaan jenis lain, seperti semak perdu sementara pohon merupakan jenis tanaman yang paling buruk menahan benturan.

Penataan maupun pemilihan tanaman untuk fungsi ini belum terpenuhi meskipun ada fungsinya belum terpenuhi secara maksimal. Untuk tujuan tersebut penataan tanaman dapat dilakukan dengan memilih jenis-jenis pohon yang memiliki batang/ cabang yang lentur dan memiliki percabangan yang padat.

\section{Penahan Angin}

Pada lokasi studi $46,15 \%$ responden menyatakan buruk, 30,77\% menyatakan baik dan 23,08\% menyatakan sangat baik. Pada taman tepi jalan tersebut kondisi jalan yang memanjang dan keberadaan tegakan pohon di kiri dan kanan jalan yang membentuk koridor dapat menghindarkan terjadinya turbulensi angin, sehingga udara dapat mengalir. Aliran udara yang lancar dapat menciptakan kesejukan, selain itu dapat berfungsi untuk menurunkan suhu. Pada tepi jalan keberadaan tanaman pada sisi kanan dan kiri ruas jalan sehingga fungi penahan angin terpenuhi. Jenis tanaman yang digunakan seperti palem raja sudah memenuhi persyaratan namun tanaman ini belum bertungsi optimal karena sudah banyak yang tua.

Tanaman dapat mengontrol dan memodifikasi angin dengan menghalangi, mengendalikan, menyaring dan mengalihkan arah angin. Besarnya kemampuan tanaman dalam mengurangi kecepatan angin tergantung pada ketinggian, kerapatan, bentuk dan lebar penanaman.

Tanaman yang dapat berfungsi sebagai penahan angin sebaiknya merupakan jenis tanaman tinggi, semak/ perdu yang tahan angin atau tidak mudah patah, bermassa daun padat, ditanam berbaris atau membentuk massa, jarak tanam rapat dan memiliki daun yang tidak mudak rontok. Jenis tanaman yang dapat digunakan antara lain cemara angin, angsana, kiara payung, tanjung dan kembang sepatu.

\section{Kontrol Kesilauan}

Pada tapak tepi $53,85 \%$ responden menyatakan buruk, dan masing-masing $23,08 \%$ responden menyatakan baik dan sangat baik. Pada segmen tersebut hal ini tidak hanya tampak dengan keberadaan tanaman disepanjang ruas jalan tetapi juga diperlihatkan oleh posisi ruas jalan yang memanjang dengan arah selatan-utara menguntungkan para pengguna jalan.

Penggunaan rumput sebagai alas telah dapat mengurangi efek silau dari pantulan sinar matahari dan perkerasan. Responden yang menyatakan buruk. dimana luasan perkerasan lebih dominan dibandingkan luasan penutupan oleh tanaman, kondisi ini merupakan potensi silau yang harus diantisipasi dengan penanaman kembali area kosong dengan tanaman atau rumput. Untuk memberi kesan melemhutkan pada perkerasan dapat digunakan jenis tanaman merambat.

Menurut Departemen PU (1996) penanaman semak atau perdu sebagai 
penahan kesilauan ditanam dengan rapat, dengan ketinggian rata-rata 1,5 $\mathrm{m}$ dan memiliki massa daun yang padat. Tanaman yang cocok untuk kriteria tersebut adalah soka, bugenvil, kembang sepatu, bunga mentega dan nusa indah.

\section{Peneduh}

Pada segmen tepi jalan, 38,46 $\%$, responden menyatakan buruk, dan masing-masing $30,77 \%$ responden menyatakan baik dan sangat baik. Sedangkan untuk segmen median jalan 53,85\% responden menyatakan baik, 30,77 menyatakan buruk dan masing-masing $7,69 \%$ menyatakan sangat baik dan sangat buruk Untuk fungsi ini semua segmen dinyatakan baik.

Berdasarkan pengamatan lapang, ruasan DAMIJA didominasi oleh tegakan pohon palem raja, kanopikanopi pohon tidak saling menyatu sehingga secara otomatis terbentuk suatu lingkungan dengan iklim mikro yang sejuk dan tidak terlalu lembab.Kesatuan daun dan batang, melindungi lingkungan dibawahnya dari panas sinar matahari. Demikian juga pada median jalan di sebagian segmen, kanopi antar tanaman saling bersinggungan menutupi lingkungan dibawahnya. Pada median jalan jenis tanaman yang digunakan didominasi oleh jenis semak/ perdu dan jenis pohon yang berukuran belum dewasa sehingga keteduhan yang dihasilkan belum optimal.

Kondisi ini sangat menguntungkan bagi pengguna jalan raya terutama bagi pejalan kaki. Menurut Sulistyantara (1995), suhu permukaan elemen di bawah kanopi pohon mencapai $28-29^{\circ} \mathrm{C}$, suhu permukaan semak $28-33^{\circ} \mathrm{C}$, suhu permukaan tanaman penutup tanah dan rumput $35-36^{\circ} \mathrm{C}$ dan suhu permukaan aspal mencapai diatas $50^{\circ}$.

\section{Penahan Erosi}

Pada segmen tepi jalan 46,15\% responden menyatakan buruk, masingmasing 23,08\% menyatakan baik dan sangat baik dan 7,69\% menyatakan sangat buruk. Pada tapak permukaan tanah relatif datar, nilai presentase tertinggi ditunjukkan oleh tingkat penutupan rumput yang merata. Untuk mengantisipasi kemungkinan terjadinya erosi, pada lokasi studi, digalakkan penanaman rumput. Jenis tanaman yang digunakan adalah rumput paitan. Tanaman penutup tanah ini memiliki akar yang mampu mengikat partikelpartikel tanah, pertumbuhannya cepat dan mampu hidup ditanah yang kurang subur. Disamping itu penanaman rumput ini juga dapat berfungsi untuk memperbaiki iklim mikro dan juga untuk mengurangi silau dari pantulan perkerasan.

\section{Peredam Kebisingan}

$$
\text { Pada segmen tepi jalan }
$$
$53,85 \%$ responden menyatakan buruk, $30,77 \%$ menyatakan sangat baik dan $15,38 \%$ menyatakan baik.Pada segmen ini penggunaan lahan didominasi oleh pemukiman. Responden menyatakan baik yang diperlihatkan dengan adanya keberadaan pohon di sepanjang segmen tersebut.

Tingkat kebisingan yang ditimbulkan jalan raya dan jalan bebas hambatan pada umumnya adalah 60-75 dB (Harris dan Dines, 1988). Menurut Simonds (1983) kebisingan dapat menyebabkan kepala dan perasaan tidak enak serta dapat mengganggu pendengaran dan bahkan menyebabkan ketulian. Pengendalian kebisingan pada tapak dapat dilakukan 
dengan memberi barrier fisik berupa vegetasi (disepanjang ruas jalan), dinding penghalang.

Tanaman dapat digunakan untuk mengurangi kebisingan meskipun tidak menghilangkan sama sekali, penanamannya adalah dengan kerapatan yang tinggi sehingga menyerupai tembok atau penghalang bangunan. Pada lokasi studi hal ini belum dilakukan mengingat terbatasnya area penanaman. Pada segmen tepi jalan yang dimiliki DAMIJA cukup lebar masih memungkinkan untuk dilakukan penataan tanaman berdasarkan strata tajuk tanaman (komposisi vertikal) dengan mengkombinasikan penanaman pohon, semak/ perdu dan ground cover. Menurut penelitian Novia (1998), tanaman yang baik untuk peredam kebisingan adalah bambu dan jenis jenis cemara kipas, cemara lilin dan tusam.

\section{Pereduksi Polusi}

Pendapat responden pada segmen tepi jalan $46,15 \%$ responden menyatakan baik, masing-masing $23,08 \%$ responden menyatakan sangat baik dan buruk serta 7,69\% menyatakan sangat buruk.

Pada lokasi penelitian jenis tanaman palem raja yang memiliki serapan rendah terhadap polutan dengan tingkat serapan ${ }^{15} \mathrm{~N}$ sebesar 11,74 $\mu \mathrm{g} / \mathrm{g}$, sedangkan kihujan memiliki serapan yang tinggi yaitu $35.37 \mu \mathrm{g} / \mathrm{g}$ (Nassrullah et al, 1997)

Grey dan Deneke (1978) menambahkan bahwa tanaman yang daunnya memiliki rambut merupakan salah satu karakteristik tanaman yang dapat menjerap dan menahan debu. selain itu tanaman yang efektif untuk mengurangi polutan partikel adalah tanaman yang memiliki trikoma tinggi atau memiliki bulu daun, bergerigi atau bersisik.

\section{Pemberi Identitas}

Pada segmen tepi jalan 69,23\% responden menyatakan baik dan $30,77 \%$ menyatakan sangat baik. Penggunaan tanaman dengan dominasi jenis tanaman tertentu misalnya Palem raja mempunyai fungsi sebagai pemberi identitas dapat terpenuhi. Kesan monumental juga diperlihatkan dengan penggunaan tanaman palem raja yang mempunyai ketinggian $>16 \mathrm{~m}$ dan berbatang kokoh serta lurus

Fungsi identitas dimaksudkan untuk memberikan kesan yang mendalam sehingga pengguna jalan dapat mengetahui dirinya akan memasuki atau keluar dari ruas jalan ini hanya dengan melihat tata hijau di sekitarnya. Pola penanaman yang berjajar dengan penanaman jenis tumbuhan yang sama sepenuhnya dapat menciptakan identitas lokasi. Identitas lokasi dapat tenwujud jika kontinyuitas pananaman, seperti jarak tanam ideal telah dilakukan.

Penggunaan tanaman dengan variasi jenis yang cukup tinggi menyebabkan biasnya tema yang ingin ditampilkan sehingga fungsinya sebagai pemberi identitas belum terpenuhi. Kesan monumental sudah diperlihatkan dengan penggunaan palem raja yang ditata secara simetris, namun masih perlu diperhatikan kondisi tanaman yang digunakan.

\section{Penilaian Aspek Estetika Tanaman Tepi Jalan}

Tata hijau untuk fungsi estetika dimaksudkan untuk menciptakan pemandangan yang indah dan membentuk harmonisasi dengan lingkungan sekitarnya. Pada lokasi studi pohon-pohon yang digunakan umumnya memiliki nilai estetika tersendiri, seperti mahoni yang memiliki daun 
berwarna gelap dan mengkilap; kihujan memiliki keindahan pada bentuk tajuk, palem raja memiliki keindahan pada bentuk batang dan juga bentuk tajuk tanaman.

Penilaian responden dalam pemilihan tanaman menunjukkan pada segmen tepi jalan $46,15 \%$ responden menyatakan sangat baik, 38,46\% menyatakan baik dan 15,38\% menyatakan buruk. Pada segmen median jalan, responden yang menyatakan sangat baik sebanyak $53,85 \%$ dan $46,15 \%$ menyatakan baik. Secara keseluruhan hasil penilaian responden untuk pemilihan tanaman menyatakan sangat baik.

Pendapat responden terhadap pengaturan tanaman pada segmen tepi jalan menyatakan baik dan sangat baik masing-masing sebanyak $38,46 \%$ dan $23,08 \%$ menyatakan buruk, sedangkan pada segmen median jalan responden menyatakan $53,85 \%$ baik dan $46,15 \%$ menyatakan sangat baik..

Secara umum responden menyatakan bahwa pemilihan dan pengaturan tanaman pada DAMIJA sudah baik. Estetika tanaman lebih terlihat pada lokasi sepanjang depan Gereja Katedral Ijen sampai dengan ujung jalan Ijen, dimana dengan pemilihan jenis tanaman yang sama (palem raja) dan pengaturan berbaris, teratur dan kontinyu memberikan kesan indah dan juga mempunyai karakteristik khusus pada jalan ijen, hal ini didukung pula dengan keberadaan desain bangunan sekitar jalan ijen yang menunjukkan nilai histotis (kolonial).

Pengaturan tanaman disusun sedemikian rupa untuk memberi kesan kokoh dan memberi ciri khusus serta tema yang jelas. Penataan tanaman menampilkan suatu kesatuan, keberadaan tarnan ini menjadi penting sebagai pemecah dominansi perkerasan .

Pada segmen tepi jalan tingkat keragaman tanaman yang rendah menonjolkan karakter lanskap yang dicirikan oleh penanarnan pohon palem rajadisepanjang jalur hijau tepi. Kesan rapi dan seimbang sudah terlihat namun masih terasa monoton tanpa adanya kombinasi penanaman pohon, sernak/perdu maupun ground cover. Selain itu pemandangan pada segmen ini ditunjang pula oleh penggunaan lahan yang didominasi oleh pemukiman dengan gaya disain kolonial Belanda.

Segmen tepi jalan memiliki karakter lanskap yang berbeda dengan jalur hijau lainnya di kota Malang. Keberadaan jalur hijau kota Malang menjadi landmarkKota Malang, dan menjadi nilai tambah pemandangan pada jalur hijau ini.Ciri lainnya adalah adanya pohon-pohon tua bernilai sejarah yang tetap dijaga keberadaannya yaitu kihujan, mahoni dan palem raja. Kehadiran jenis tanaman tersebut menciptakan bayangan tajuk pohon yang menutupi hampir seluruh permukaan jalan, dengan bentuk tajuk dan percabangan yang menarik. Ukuran tanaman besar menjadi nilai tambah pada jalur hijau ini. Pada siang hari bayangan membentuk suatu pola-pola bayangan yang dinamis pada jalan beraspal. Kehadiran pedestrian yang nyaman dan barisan display tanaman sekitar lokasi juga merupakan daya tarik tersendiri. Pada jalur hijau di sisi kiri pedestrian dipadukan dengan penataan tanaman yang memiliki keragaman warna, tekstur dan ketinggian dengan pola garis organik. Segmen ini memiliki tingkat keragaman yang cukup tinggi.

Untuk menghilangkan kemonotonan, pada lokasi studi, telah dilakukan disain dengan menerapkan pola organik dalam penataan semak/ 
perdu dan ground cover. Selain itu penggunaan warna-warna kontras sebagai aksen telah dapat memecah kemonotonan. Menurut Sulistyantara (1995), dengan adanya suatu titik perhatian maka bisa menggugah semangat, menghidupkan suasana, memecah kejenuhan atau kemonotonan yaitu dengan cara membuat suatu kontras atau membuat suatu pola susunan tertentu.

\section{Penilaian Aspek Agronomis Tanaman Tepi Jalan}

Tanaman yang digunakan sebagian besar merupakan jenis tanaman yang mudah tumbuh dan tidak memerlukan perawatan khusus. Berdasarkan pengamatan lapang diperoleh nilai aspek agronomis tanaman untuk tanaman tepi jalan, kembali didominasi oleh barisan tegakan palem raja pada kedua sisi ruas jalan. Segi ekologi tanaman palem raja mempunyai kesesuaian terhadap suhu tinggi, kelembaban kering, cahaya terbuka, $\mathrm{pH}$ netral, kecepatan angin rendah.

\section{Jarak Tanam dan Lokasi Penanaman}

Pergamatan dilapang memperlihatkan bahwa jarak tanam pohon pada umumnya berkisar antara 6 $m$ dengan kondisi kanopi yang tidak terkait. Untuk jenis semak/ perdu dan ground cover jarak tanam disesuaikan dengan bentuk dan pola yang akan diciptakan, disesuaikan pula dengan ruang tumbuh yang tersedia. Namun hal tersebut telah di antisipasi dengan adanya upaya penanaman kembali pohon-pohon kecil di lokasi serta di antara pohon besar yang telah tua. Pada beberapa segmen penutupan ground cover tidak merata akibat intensitas injakan yang tinggi menyebabkan pemadatan tanah yang bedampak pada kematian rumput.

\section{Kondisi Pertumbuhan}

Secara umum tanaman memiliki kondisi pertumbuhan yang baik. Pada segmen tepi jalan, kondisi tanaman untuk jenis pohon dan semak/perdu memiliki kondisi fisik yang baik dengan kerusakan minimal. Untuk jenis ground cover kondisi tanah yang memadat akibat intensitas injakan pada jalur hijau di ruas kanan jalan yang tinggi menyebabkan kematian rumput. Sepanjang segmen ini rumput hanya tumbuh dengan baik pada median jalan.Kerusakan lainnya terjadi akibat vandalisme, seperti coretan maupun pelukaan pada batang pohon.

\section{Pemeliharaan}

Pemeliharaan tanaman ditujukan untuk menjaga dan merawat kondisi tanaman agar tumbuh dengan baik. Bentuk pemeliharaan yang dilakukan adalah penyiraman, penyulaman, pemangkasan, pemupukan dan pemberantasan hama dan penyakit tanaman.Tingkat pemeliharaan bervariasi

Untuk menjaga kelangsungan hidup tanaman-tanaman ini, dilakukan perawatan yang intensif yaitu dengan mengganti tanaman yang rusak atau mati, menjaga ketersediaan unsur hara pada media tanam sehingga unsur hara yang terdapat pada bak tanaman dapat tercukupi.

Pernangkasan pohon dan perdu sudah dilakukan dengan baik sehingga sirkulasi pengguna jalan tidak terganggu. Penebangan pohon yang sudah tua ataulapuk dilakukan apabila ada permintaan dari warga karena pohon tersebut mengganggu kepentingan dan keselamatan warga.Pemupukan dan penyulaman tanaman dilakukan jika diperlukan. 
Pada umumnya pemupukan dilakukan di awal penanaman untuk selanjutnya pemupukan hanya diberikan pada tanaman semak/perdu, ground cover dan pohon yang muda. Penyulaman dilakukan untuk tanaman yang pertumbuhannya tidak normal adakalanya tanaman diganti dengan jenis lain. Penyulaman pohon dilakukan diantara pohon-pohon tua sebagai upaya regenerasi.

\section{Rekomendasi}

Kerangka pemikiran rekomendasi untuk mengoptimalkan fungsi, estetika dan tindakan agronomis pada tanaman tepi jalan, khususnya di Jalan Ijen, Kota Malang yaitu: upaya penataan dan pemilihan jenis tanaman yang fungsional dan estetis ditunjang oleh aspek agnonomis yang baik.

\section{Aspek Fungsi}

Fungsi pengarah pada DAMIJA ditujukan untuk keselamatan mengemudi. Fungsi ini pada lokasi studi dapat diupayakan dengan penanaman yang kontinyu pada semua segmen (Tepi jalan dan median jalan), untuk jenis tanaman berbatang tunggal dan untuk memberi kesan lembut pada perkerasan digunakan jenis tanaman penutup tanah.

Fungsi tanaman sebagai pembatas, kontrol silau, penahan benturan dan penahan angin merupakan fungsi untuk mencegah kecelakaan. Pada lokasi studi, paduan tanaman dengan pagar sebagai pembatas dapat menjadi alternatif penataan tanaman terutama pada daerah dengan aktivitas tinggi. Penggunaan jenis semak/ perdu yang memiliki elastisitas tinggi dapat digunakan sebagai penahan benturan. Penerapan tanaman sebagai kontrol silau sebaiknya diterapkan pada seluruh segmen jalan dengan penanaman semak yang rimbun, memiliki kecepatan tumbuh sedang, tahan kering dan dengan ketinggian 1-1,5 m. Fungsi tanaman sebagai penahan angin dapat rnenggunakan jenis tanaman tinggi, semak/perdu yang tahan angin, tidak mudah patah, berdaun padat, ditanam berbaris atau berkelompok, jarak tanam rapat dan memiliki daun yang tidak mudah rontok.

Fungsi peneduh dapat diupayakan dengan penanaman jenis pohon bertajuk bulat, maupun menyebar secara kontinyu dalarn jarak yang memungkinkan tajuk tanaman tidak saling bersinggungan.

Berdasarkan frekuensi, kerapatan dan dominansi pada lokasi studi jenis palem rajamemiliki nilai tertinggi, hal ini merupakan potensi yang dapat dikembangkan untuk menciptakan identitas lokasi

\section{Aspek Estetika}

Pemilihan jenis tanaman harus dapat memberi estetika ataupun sebagai penyangga lingkungan. Pemilihan tanaman sebaiknya tidak menggunakan tanaman-tanaman yang bernilai eksotis tinggi karena selain pemeliharaannya sulit, daya tariknya dapat mengganggu konsentrasi pengemudi. Penataan dengan pola sederhana akan menghemat biaya pemeliharaan.

Tanaman yang dikomposisikan dengan baik akan menciptakan variasi pemandangan, sehingga dapat mencegah kesan monoton dalam lingkungan jalan. Kemonotonan dapat dieliminir dengan adanya kontras baik melalui warna, tekstur tanaman maupun tanaman tinggi. Sebaiknya tanaman disajikan secara massal dengan perubahan tiap jenis minimal sepanjang 240-320 m agar pengguna jalan dapat menangkapkesan warna, bentuk maupun tekstur dari tanaman. Pada lokasi studi sebaiknya tanaman ditanam secara 
memanjang. Disamping itu tanaman dapat memberi ciri khas jalan atau identitas lokasi melalui penataan yang memiliki kesatuan tema.

\section{Aspek Agronomis}

Tanaman yang memiliki kondisi pertumbuhan yang baik akan mendukung fungsi secara optimal dan dapat memberikan keindahan pemandangan. Agar tanaman dapat tumbuh dan beradaptasi dengan baik harus diperhatikan persyaratan tumbuh tanaman. Dalam memilih jenis tanaman tepi jalan disarankan untuk menggunakan tanaman yang sesuai dengan kondisi iklim dan tanah 2 perakaran tidak merusak konstruksi jalan, mudah dalam perawatan, batang kokoh/ tidak mudah patah dan tidak menggugurkan daun. Penggunaan tanaman musiman sebaiknya dihindari.

Untuk mengoptimalkan kondisi pertumbuhan tanaman, perlu dilakukan upaya pemeliharaan yang intensif mulai dari penyiraman, penyulaman, pemangkasan, pemupukan dan pemberantasan hama dan penyakit tanaman. Pemilihan jenis tanaman lokal atau asli daerah maupun tanaman yang telah beradaptasi dengan baik dapat meringankan beban pemeliharaan.

\section{KESIMPULAN}

Keberadaan tanaman pada jalur hijau di kawasan perkotaan memiliki arti penting dalam mengantisipasi dampak negatif perubahan wajah kota. Dari hasil evaluasi, disimpulkan bahwa kualitas tanaman dari segi fungsi, estetika dan agronomis di Jalan Ijen dapat disimpulkan sebagai berikut:

1. Fungsi tanaman sebagai pengarah terdapat pada segmen tepi jalan namun belum efektif. Fungsi pembatas lebih berfungsi sebagai penghalang fisik. Fungsi penahan benturan, belum dimiliki. Fungsi penahan angin tercipta oleh panataan tanaman yang membentuk koridor. Fungsi tanaman sebagai kontrol silau terpenuhi. Fungsi peneduh secara umum telah terwujud. Fungsi tanaman sebagai pencegah erosi terdapat pada segmen median jalan. Fungsi tanaman sebagai peredam bising dan identitas terpenuhi pada segmen tepi jalan yaitu dengan adanya palem raja.

2. Penilaian terhadap aspek estetika diperoleh dari pemilihan jenis tanaman dan penataan tanaman masih perlu ditingkatkan untuk mendukung fungsi yang akan dikembangkan. Secara agronomis, jenis tanaman yang ada cukup menunjang keberadaan fungsi dan estetika tanaman.

3. Ketepatan dalam pemilihan jenis tanaman dan penataan serta pengelolaan elemen lanskap jalan raya merupakan kunci keberhasilan lanskap jalan yang fungsional dan estetis sesuai fungsi yang akan dikembangkan.

\section{UCAPAN TERIMA KASIH}

Penulis menyampaikan rasa terimakasih kepada DP2M Dikti atas peneyediaan dana yang menunjang pelaksanaan penelitian tersebut

\section{DAFTAR PUSTAKA}

Anonymous.1989. Petunjuk Umum Penghijauan. Pemerintah Daerah Dati II. Surabaya.

Anonymous.1995. Pemanfaatan Ruang Terbuka Hijau Di Surabaya. Dinas Pertamanan Daerah. Pemerintah Kotamadya Dati II Surabaya. 
Anonymous.1999. Penataan Taman Yang Padat Alami Bergaya Tropis. Griya Asri. Yayasan Estetika Prima. Jakarta No. 18 / Hal.56-60.

Arifin, H. 1993. Pemeliharaan Tanaman Majalah Asri No. 164 terbitan Bulan November 1996.Penerbit Swadaya. Jakarta.

Arifin dan Nurhayati. 1996. Pemeliharaan Taman. Penebar Swadaya. Jakarta.

Dahlan, E.N. 1992. Hutan Kota Untuk Pengelolaan Dan Peningkatan Kualitas Lingkungan Hidup.Asosiasi Pengusaha Hutan Indonesia (APHI). Jakarta. 92 hal.

Leni Uswatun. 1999. Pelaksanaan Penghijauan Kota DI Wilayah Kotamadya Malang.Laporan Praktek Kerja Lapang Program Studi Arsitektur Pertamanan Fakultas Pertanian Universitas Brawijaya Malang.

Nazaruddin. 1996. Penghijauan Kota. Penebar Swadaya. Jakarta. 120 hal.

Nurisjah dan Pramukanto. 1995. Penuntun Praktikum Perencanaan Lanskap Program Studi Arsitejtur Pertamanan Jurusan Budidaya Pertanian. IPB. Bogor. (Tidak dipublikasikan).

Soeseno, Slamet. 1993. Taman Indah Halaman Rumah. Gramedia Pustaka Utama. Jakarta.

Suharto. $1998 . \quad$ Dasar-Dasar Pertamanan: Menciptakan
Keindahan dan Kerindangan. Media Wiyata. Semarang.

Sulistyantara, B. 1992. Taman Rumah Tinggal. Penerbit Swadaya. Jakarta. 194 hal.

Tim Studi BDP IPB. 1993. Panduan Pemeliharaan Tanaman Di Padang Golf. P.T. Citraland Surya. Padang Golf. Surabaya

Zoer'aini, D.I. 1992. Tantangan Lingkungan dan Lanskap Hutan Kota. PT Pustaka CISENDO. Jakarta. 300 hal. 